\title{
HISTORY OF HOLY TRINITY CHURCH IN PYATAYA GORA HOMESTEAD OF TSARSKOSELSKY COUNTY AND CHOICE OF METHOD OF ITS RESTORATION
}

\author{
Nadezhda Akulova1, Yekaterina Voznyak², Yulia Ardasheva ${ }^{3}$ \\ 1,2,3 Saint Petersburg State University of Architecture and Civil Engineering \\ Vtoraja Krasnoarmejskja ul. 4, St. Petersburg, 190005, Russia \\ ${ }^{1}$ naroma@list.ru, ${ }^{2}$ vozniak65@mail.ru, ${ }^{3}$ ArJuli@yandex.ru
}

\begin{abstract}
This research covers the Holy Trinity Church, a monument of church architecture located in Pyataya Gora homestead of the Tsarskoselsky County, today's Volosovsky district of the Leningrad region. The article is devoted to the study of architectural development of the territory of the estate of O. K. Briskorn Pyataya Gora and the history of construction of Holy Trinity Church. The study includes the analysis of the territory of Volosovsky district as local geographic and municipal area in the framework of the subject topic. The history of the area development and construction of the church was examined based on the preserved archival document "Statement of Inventory... prepared by priest loannes Shkorbatov", the archives of the Trinity Church in Pyataya Gora homestead and the studied "Inventory of the church property" dated May 1829. We also used the measurement drawings of the SPSUACE students performed in 2015.

The study performed resulted in the development of the design proposal on renovation of the area around the church. The proposal is aimed at promotion of the studied area and inclusion of the Pyataya Gora estate in the architectural background of the district.
\end{abstract}

Keywords: Pyataya Gora homestead, rotunda church, the Tsarskoselsky County, restoration, classic architecture, column order.

\section{Introduction}

Study and restoration of monuments in the Leningrad region is a topic issue of preservation of the architectural heritage. Tsarskoselsky County is one of the most important cultural centers of the Petersburg province, possessing a large number of cultural facilities both of civil and church architecture. Monuments located near St. Petersburg are widely known and under the spotlight of the society that keeps them in good repair. A different situation refers to the monuments located in remote, often sparsely populated regions. Architectural objects located in the relative remoteness are often destroyed and need additional protection. The loss of these objects will be not only the loss of an architecture monument, but also the loss of a historical cultural landscape leaving a gap in cultural memory of people. One of the outstanding monuments of church architecture of the Tsarskoselsky County is Holy Trinity Church in Pyataya Gora homestead of today's Volosovsky district. A centric church constructed on the top of the hill in XIX century is an important landscape spot both for the village and the surrounding areas. It is visible from far away, but nowadays its ruins is a sorrowful centerpiece of the surrounding landscape. Restoration of this monument of architecture is the matter of interest of local and administration authorities of rural settlement Kalitino.

\section{Subject, tasks and methods}

The subject of the study is the development of the territory of Pyataya Gora homestead and the history of con- 
struction of certain architectural monument, Holy Trinity Church.

Our objective was the selection of the restoration method for the regional architectural monument and development of the design proposal on renovation of the adjacent estate territory.

The tasks of the study are the following:

- Identification of significance of the former Pyataya Gora homestead within the municipal area, as well as in the context of the existing historical and cultural landscape; determination of the ways to renovate the village area.

- Selection of the most appropriate method of the temple restoration.

Study of archival sources on the subject, analysis of functional zoning schemes, analysis of historically valuable sites for the prospects of tourism; study of regional development plan of the Leningrad region, as well as onsite study of the monument allows to deal with the issue of the significance of the village and the Holy Trinity Church in the context of historical environment and to select the most appropriate method of the church restoration.

The aspect research approach in this case involves development of the subject study in three directions: study of historical archival materials, analysis of the surrounding area as per above stated items, and, finally, renovation project for the Holy Trinity Church and adjacent territory.

The renovation project for any historical monument implies a detailed study of the history of the monument under reconstruction, which requires determination of its development periods and the analysis of the fact of whole or partial change of layout or planning pattern of the monument.

\section{Research part}

Pyataya Gora homestead is located in rural settlement Kalitino of Volosovsky district. According to the conclusion of the state historical and cultural study, "Pyataya Gora Homestead", which includes the park, the church of the Holy Trinity, the household building located in Pyataya
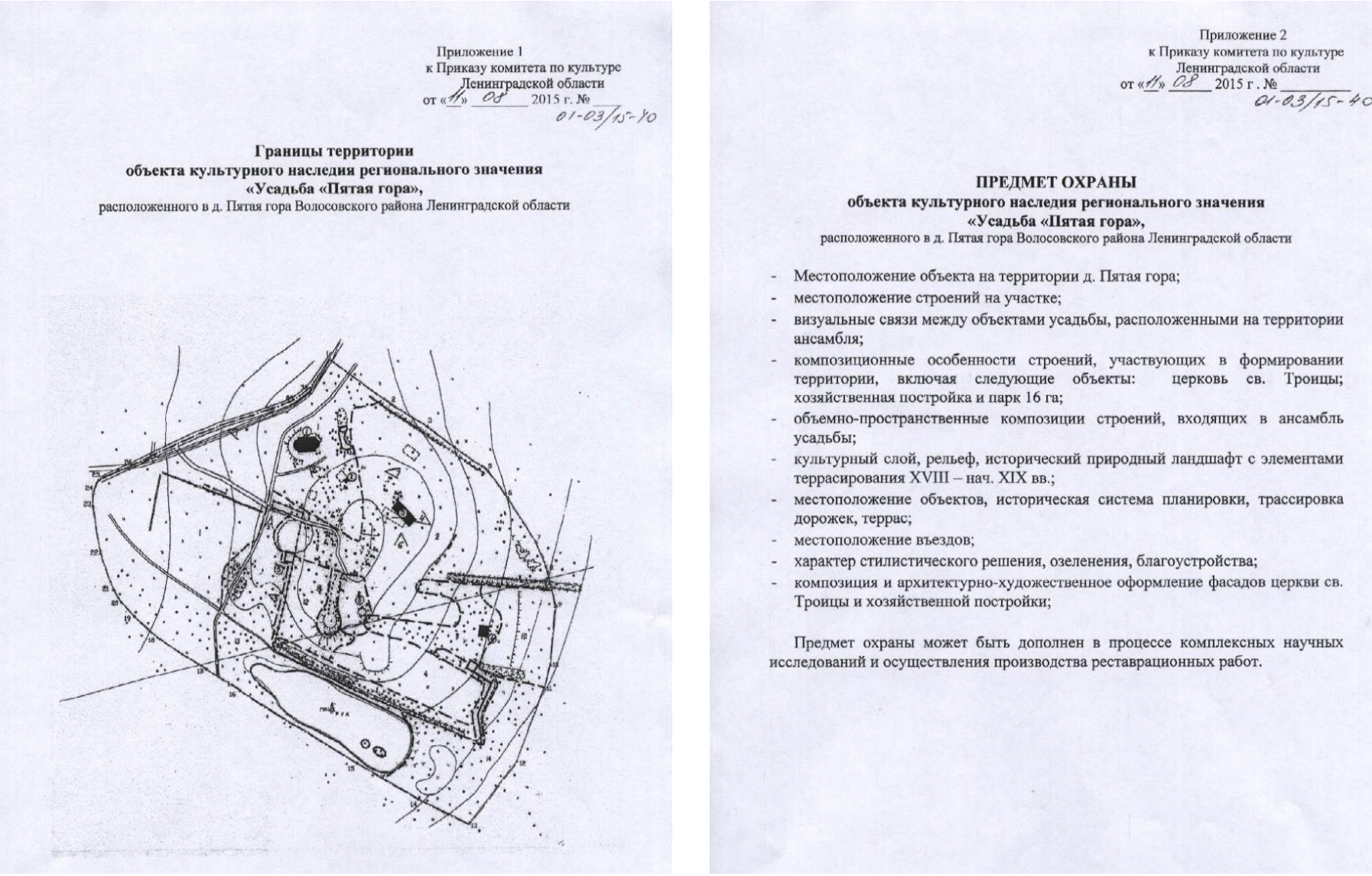

Figure 1. Borders of the territory and the protection object of the cultural heritage object "Pyataya Gora Homestead" of the regional significance ${ }^{1}$

1 Document 1 (translation): Appendix 1 to the Order of the Committee for State Control, Utilization and Protection of Historical and Cultural Landmarks of the Leningrad region No. 01-03/15-40 dd. 11/08/2015. Borders of territory of cultural heritage object "Village Pyataya Gora" of regional significance located in village Pyataya Gora of Volosovsky district of the Leningrad region.

Document 2 (translation): Appendix 2 to the Order of the Committee for State Control, Utilization and Protection of Historical and Cultural Landmarks of the Leningrad region No. 01-03/15-40 dd. 11.08.2015

OBJECT OF PROTECTION of the cultural heritage object "Village Pyataya Gora" of regional significance located in village Pyataya Gora of Volosovsky district of the Leningrad region:

- $\quad$ location of the object at the territory of village Pyataya Gora;

- $\quad$ location of buildings at the site; 
Gora village in Volosovsky district of the Leningrad region, was included in the Register of cultural heritage objects of regional significance (Order of the Committee No. 0103/15-35 dd. 13.07.2015). Order of the Committee No. 0103/15-40 dd. 11.08.2015 stated the borders of the territory and the object of such cultural heritage protection.

Prior to the beginning of XIX century, the land of the homestead belonged to the Tsarskoselsky County. Such inhabited localities as Elizavetino, Kikerino, Glumitsy, Kurkovitsy, Kalitino, Pyataya Gora, Bolshoe Zarechye are old villages. The first mention of the localities is found in cadastre books of 1499. Surrounding territories of these settlements are full of ancient burial places, while the territory of Volosovsky district, that takes its name from the words "Volos", "practice magic in the name of Volos" (tell fortune), still remains one of the most mysterious and archaeologically unexplored area.

At the end of XVIII century different noble estates appeared here; they belonged mostly to descendants from Prussia and the Baltic countries (Esthonia, Livonia and Courland). Baltic nobles preferred to settle somewhere in the middle of the way from their native lands to the Russian capital. Among the owners of estates one may meet such names as the Wrangels, the Veimarns, the Stackelbergs, the Frederiks, the Ragulovs, the von Korffs, the Osten-Sackens, the von Dubelts and others.

The Pyataya Gora homestead was mentioned for the first time in 1747. Then, it belonged to German Lieutenant Colonel I. I. Plat. "Short economic notes of the Rozhdestvensky County" compiled in the end of the XVIII century stated that "Pyataya Gora homestead belonged to Lieutenant Colonel Ivan Ivanovich Plat and then came into possession of the Premier Major Kateryna Mikhaylovna Renkevich" (Short economic notes..., 1789). Then, Christiana Mikhaylovna Phocas, sister of Catherine Rankevich, the wife of the Major General, became the owner of the country house in Pyataya Gora. In 1805, Senator Theodore Maksimovich Briskorn bought the estate. After Briskorn's death, the house passed to his widow Olga Konstantinovna, then to their daughter Elizabeth, her married name Levshina, who owned it until 1844, when the Briskorns ceased their possession of the estate. It was exactly in the time of the Briskorns' possession of Pyataya Gora estate when the church in the name of the Holy Trinity, that we are discussing, was built. What is so interesting and remarkable about this church? Why is it necessary to preserve and restore it, and how to do this?

Holy Trinity is a centric temple. Its architectural solutions and the layout are identical to another two churches:
Pokrovskaya Church in Prilepy homestead of the Kursk province of the Dmitrievsky County (purchased by O.K. Briskorn in 1809) and Church of Exaltation of Holy Cross in village Vyshetarasovsokoe in the Ekaterinoslavskaya province, which also was owned by the Briskorns. Holy Trinity church, Pokrovskaya church and church of Exaltation of the Holy Cross were built according to the same design and are of centric temple type. It should be noted that construction of centric (including rotunda) churches is quite rare in Russia. Such churches were built in the estates of the nobility and representatives of the wealthiest strata of the Russian society, as a rule. Often, great landowners were the customers. The construction period of this type of churches lasted from the end of XVIII century to the first third of XIX century. The authors of engineering designs of these churches were well-known architects of St. Petersburg and Moscow, such as V. I. Bazhenov, M. F. Kazakov, N. A. Lvov, O. I. Bove, I. E. Starov. Churches of centric composition were not widespread in the Russian religious architecture, since they did not comply with the Orthodox ceremonials and the Russian traditions of church construction. These churches are represented by single monuments, most of which were completed with refectories and bell towers damaging the typological feature of such churches. There are several centric churches remained in St. Petersburg: Church of the Holy Prophet Elias (architect F. I. Demertsov, construction period of 1781-1785), Church of the Annunciation in village Staraya (architect I. N. Mochulsky, construction period of 18051809), Church "Easter cake and pudding" (architect N. A. Lvov, construction period of 1785-1790). All of them were somewhat distorted by subsequent reconstructions.

Centric composition of churches originated in Europe, having appeared in the end of XV century in Italy (in the form of rotunda-shaped churches) and later spread to Poland and Ukraine. It should be noted that the first one (the Holy Cross Church) of three mentioned churches in estates of the Briskorns was built exactly in the Ukraine; only after that, Church of the Intercession of the same design project was built, and the last was extant church in Pyataya Gora homestead.

The history of the Church may be divided into three periods: the period of 1830-1879 (construction and operation of the church), the period of 1897-1933 (abolition of the township and overhauling), the period of 1930-2016 (destruction and registration as the cultural heritage site).

The period of 1830-1879. O. K. Briskorn wrote in her petition to the Synod, asking for a permission to build a stone church (officially, her daughter already owned the

visual connections between villages located on the territory of the ensemble;

compositional features of buildings involved in formation of the territory, including the following sites: the Church of the Holy Trinity, a household facility and a 16 ha park;

three-dimensional arrangement of buildings belonging to the village ensemble;

a cultural layer, relief, historical elements of natural landscape with terracing of XVIII to early XIX centuries:

location of objects, historical planning system, layout of paths and terraces

location of access roads;

aspects of stylistic solutions, landscaping and improvements;

composition and architectural decoration of front faces of the Holy Trinity Church and the household facility.

The protection object may be enhanced in the course of comprehensive researches and restoration works. 
estate): "I have an estate in the Tsarskoselsky county, known known as Pyataya Gora. A half of peasants are of Lutheran Confession, while the others belong to Greek Russian Orthodoxy. The latter have to go to church in village of Dylitsy. However, Dylitsy is five or six versts (eight kilometers) away, and they have to go through marshy paths and snowstorms in winter, that is why the peasants practically do not visit the Church" (Briskorn, 1829a). Location for Holy Trinity Church was chosen based on the requirements of the beauty significance. The place was surveyed and acknowledged as "decorous", for "it is situated on a decent hill, making a pleasant view of the church and the beauty surrounding from all sides, and is located on a dry ground and a solid soil foundation, at that" (Briskorn, 1829b). By March 5, 1830 construction of the stone church was completed, and it was consecrated in the name of Holy Trinity on February 8, 1831.

Marina Artovna Arbogly, a member of the Society of Russian Estate Study, describes the church during her trip to the Leningrad region at the beginning of XIX century: "... the architect of Holy Trinity Church in Pyataya Gora completed it with rotunda under a squat dome and a small bell tower and designed semicircle apses and porches on the east and the west sides, giving an amazing plasticity and softness to the building. Sophistication of the architectural appearance was enhanced with evenly spaced 24 three-quarter ionic columns, decorating semicircles and porticos. A wide and high entablature unites the building into a single whole surrounding its perimeter and ending with gables on side faces ... Double light windows lit an ornate interior of the church hall, the walls of which are decorated with ionic semi-columns and the altar is separated with free-standing columns. Only the bell tower reminded that this was not a palace hall, but a parish church. The white stone church constructed on elevation, foreseeable from all sides, contrasted with the green background of the estate park ... And if analogue churches in the Kursk province and the Ekaterinoslav province fulfill one of the conditions for church construction of "watching" from a high bank of the river, the church in Pyataya Gora complies with another condition: it is towering above the surrounding spaciousness - Holy Trinity Church "looks" down the road. It seems that the church grows out of the landscape being its natural and integral part..." ( Arabogly, 2006).

As per structural features, the columns of the church are made of red brick, all masonry walls consist of bricks and white calcareous sinter mined in village Pudost at Gatchina. The church is finished with light-colored plastering, the color and composition of which can be defined as there are remnants on the outside walls.

Period of 1897-1933. In 1879, Holy Synod released decree of abolishment of the independent parish, as the parishioners stopped supplying the bread to the clergy. The church was attributed to the neighboring Vladimir Church in estate Dylitsy owned by the Trubetskoys. Holy Trinity Church gradually fell into decay. In 1889, it was registered that it was unsafe to perform services, as the foundation was washed out with springs and the dome had through cracks. Church facilities were fit only for demolition. Architect Fidelli examined the church in 1890 and stated that the building required overhaul. Roof was repaired the following year. The parishioners stated that "the obvious negligence of the former clergy, the elder and our ancestors has led the church to a total disrepair. Architect of Gatchina administration G. Dmitriev agreed to supervise the repairs" (Fidelli, 1890). Only in 1902 a major repair was carried out including repair of the foundation and wooden structures, renovation of plaster topping, arrangement of the basement, repair of cracks in the dome, whitewashing of faces.

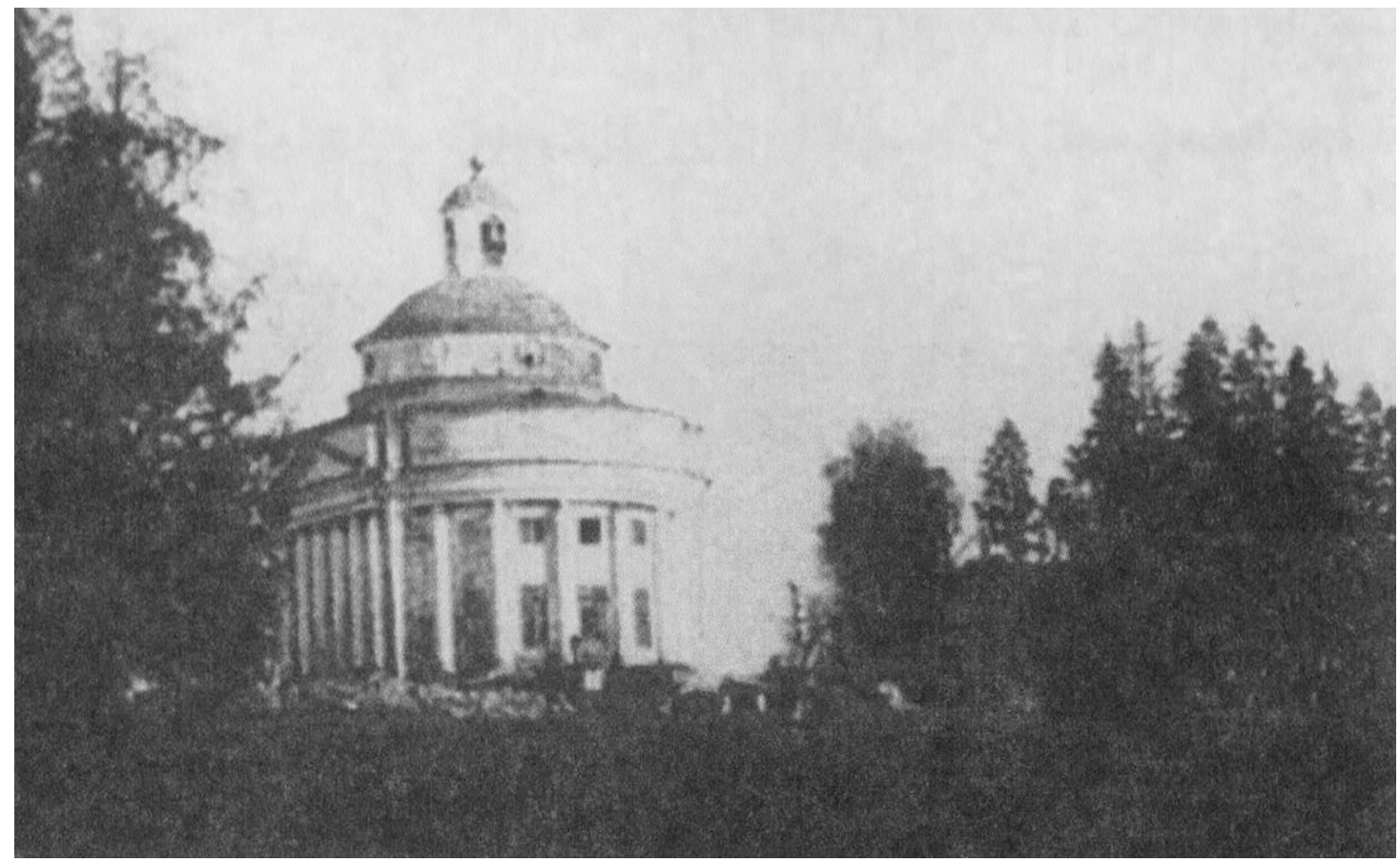

Figure 2. Holy Trinity Church in 1900s 


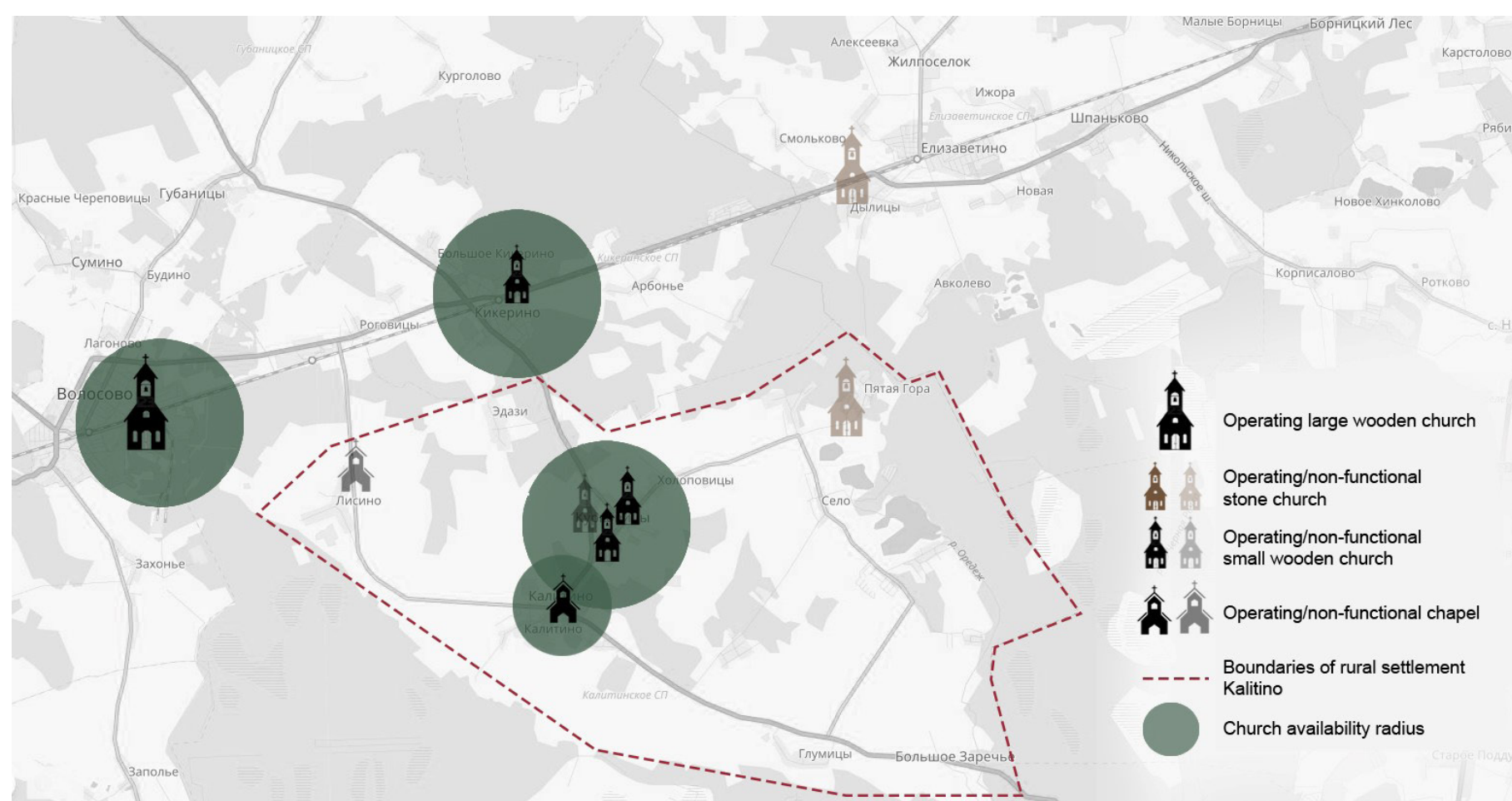

Figure 3. Layout of churches in village Kalitino of Volosovsky region

Period of 1930-2016. At the beginning of World War II, services still continued in the church, and in 1960 the dome was pulled out with tractors. In 1970s, the church partially preserved a wooden dome (Figure 2). On 14.06.1994, the church was registered as an identified object of cultural heritage. In the summer of 2015, "Pyataya Gora" historic estate and park complex in Volosovo district of the Leningrad region was declared as monument and included in the register of cultural objects. It is planned to allocate funds from the regional budget in 2016 to restore the facility. It is planned to include "Pyataya Gora" into the program "Cultural development of the Leningrad region" and to develop construction documents for its restoration.

At the present moment, there are two small operating wooden churches in the village of Kalitino; their availability radius does not overlap Pyataya Gora village and the surrounding developing cottage settlements (Figure 3). Analysis of program of regional development of St. Pe-

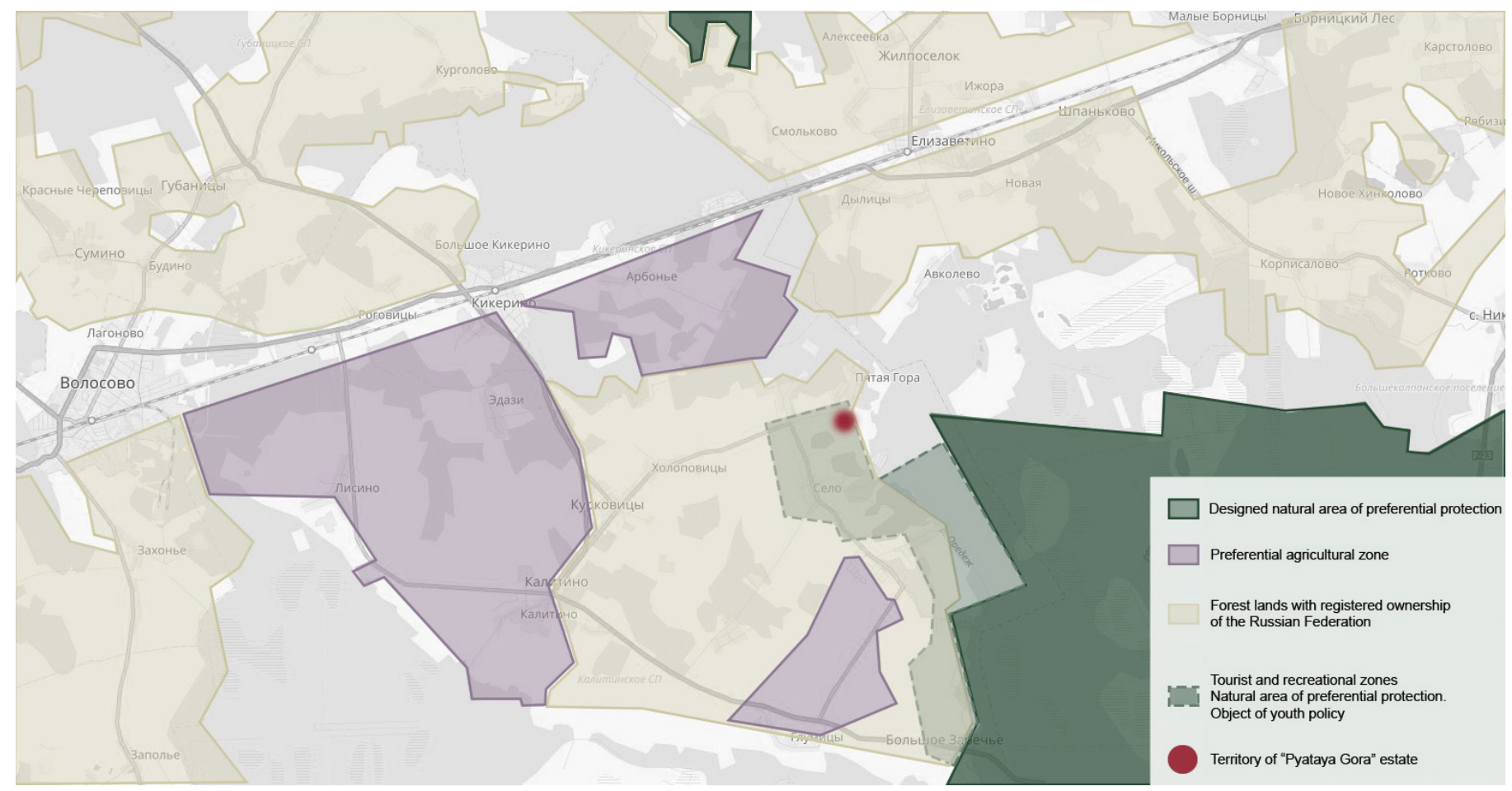

Figure 4. Layout of functional zones of the development program for Saint Petersburg and the Leningrad region 


\section{Architecture and Engineering Volume 1 Issue 3}

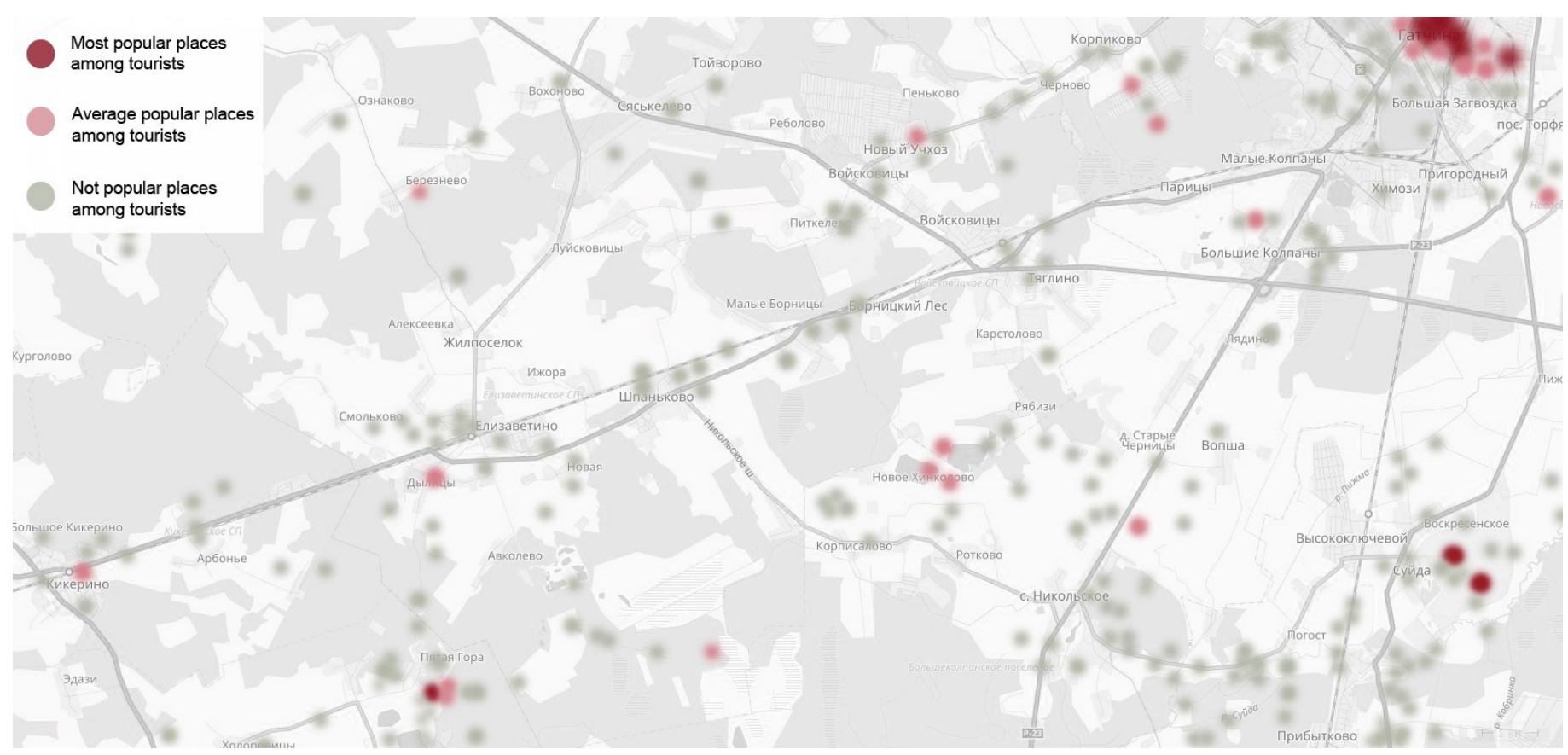

Figure 5. Layout of places of tourist attraction

tersburg and the Leningrad region indicated that the land plot of Pyataya Gora is located within the boundaries of a tourism and recreational zone of the natural area of preferential protection, referred to the objects of the youth policy. According to the scheme, agricultural production lands prevail in this area (Figure 4). Having regard to the above said, we may conclude that integration of these areas and complying with tasks of the urban planning policy of the Leningrad region should be considered while designing of the functional content of these areas in order to promote these places. Thereafter, the project should be partly aimed at young people and have tourism and recreational targets, as well as possible developing of agricultural production of the local level.

In addition, we analyzed the heat maps composed on the basis of map-referenced photos on Panoramio and Flicker sites. The cloud of points allows seeing the most interesting places where picture shooting was carried out. A layout of places for tourist attraction (Figure 5) was drawn up on the basis of the heat map. Layout reveals that "Pyataya Gora" estate is very popular among tourists. Ruins of the church are particularly interesting due to its unique space-planning solutions and the remains of household facilities on the territory of the former estate, especially it concerns the former estate house and sta-

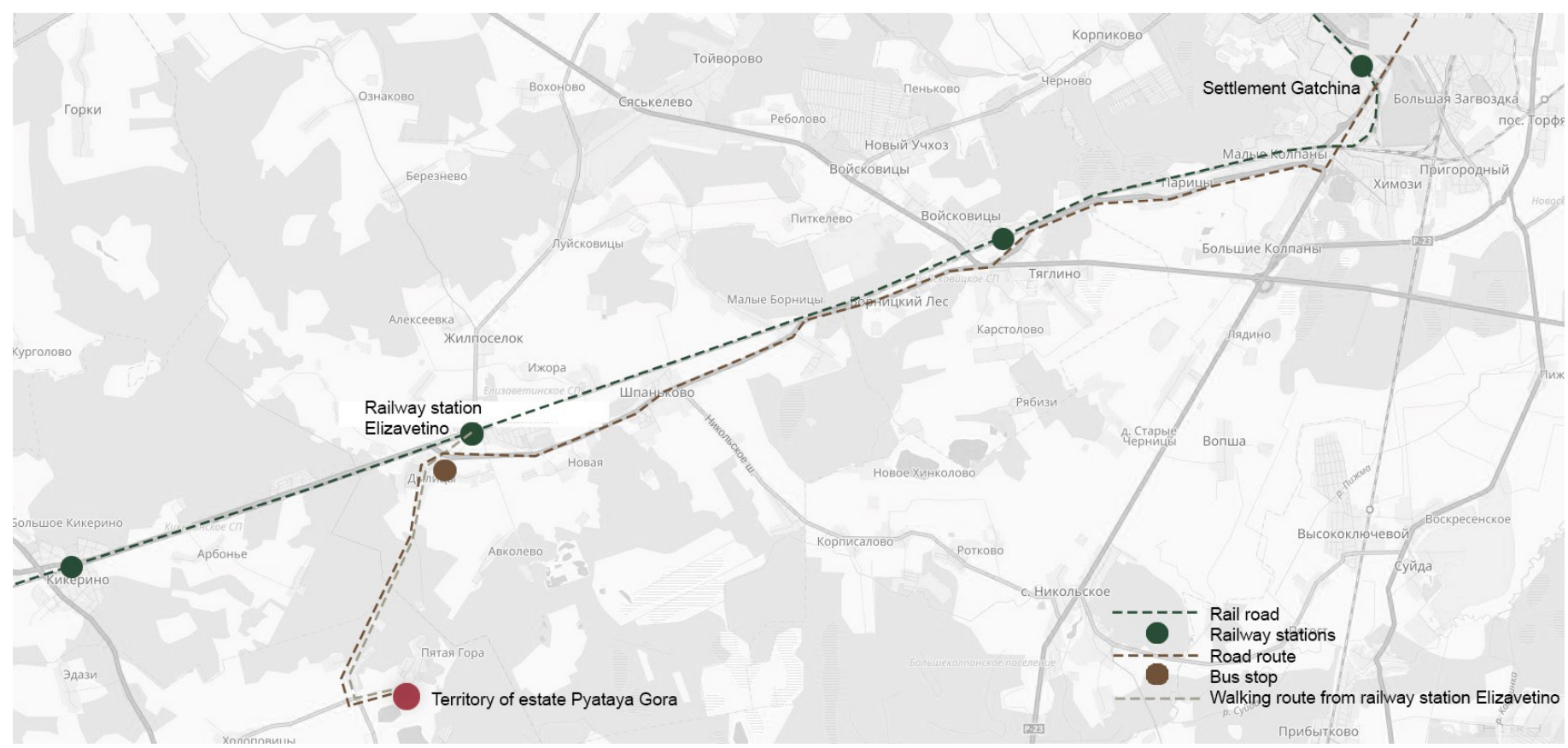

Figure 6. Scheme of transportation availability of the estate 
bles preserved at the level of foundations and the remains of a former glacier.

Local Orthodox community has constructed a large wooden cross near the ruins of the church, which proves once again that the local population wants to restore the church, but the question of the restoration type remains unsolved. What form of preservation for the architectural monument would be better: conservation in the preserved form, restoration and reconstruction of historic design or conceptual reconstruction?

According to the Venice Charter: "The process of restoration is a highly specialized operation. Its aim is to preserve and reveal the aesthetic and historic value of the monument and is based on respect for original material and authentic documents. It must stop at the point where conjecture begins, and in this case moreover any extra work which is indispensable must be distinct from the architectural composition and must bear a contemporary stamp...." (Restoration..., 1998)

Concluding the above stated, conservation of the monument in the preserved form will be most correct option with the respect to the monument itself, which meets all criteria of concept of restoration of cultural heritage object; meanwhile, restoration of the church will bring functional and economic viability to the project design proposal. These two aspects are very important for attracting investments for the purpose of current implementation of the project design and the further maintenance of the restored monument. Considering two options of reconstruction - reconstruction and conceptual restoration - reconstruction seems to be functionally, aesthetically and economically more justified. Functional justification implies the fact, that the monument of regional importance - the church of the Holy Trinity - has a complicated transport accessibility (Figure 6), and the interest of the local Orthodox population to the church requires the object to be reconstructed in its original function and be used by the residents of nearby settlements.

Economic justification derives from the functional justification: funds for reconstruction of the church could be raised from three sources: the Orthodox diocese, as it is an Orthodox church, the regional budget, since it is a monument of a regional significance, as well as investments and donations of Orthodox citizens and tourists. As for aesthetic aspects, original location of the church was chosen for the reasons of aesthetic appeal; that is why introduction of modern trends into this "landscape-architectural composition" can ruin a harmonious combination of the spirit of XIX century beginning.

Measurements of the remaining parts were carried out to draw a graphic reconstruction plan of the church. It is clear from measuring diagrams and maps of exterior defects of Holy Trinity Church drafted during period of 2015
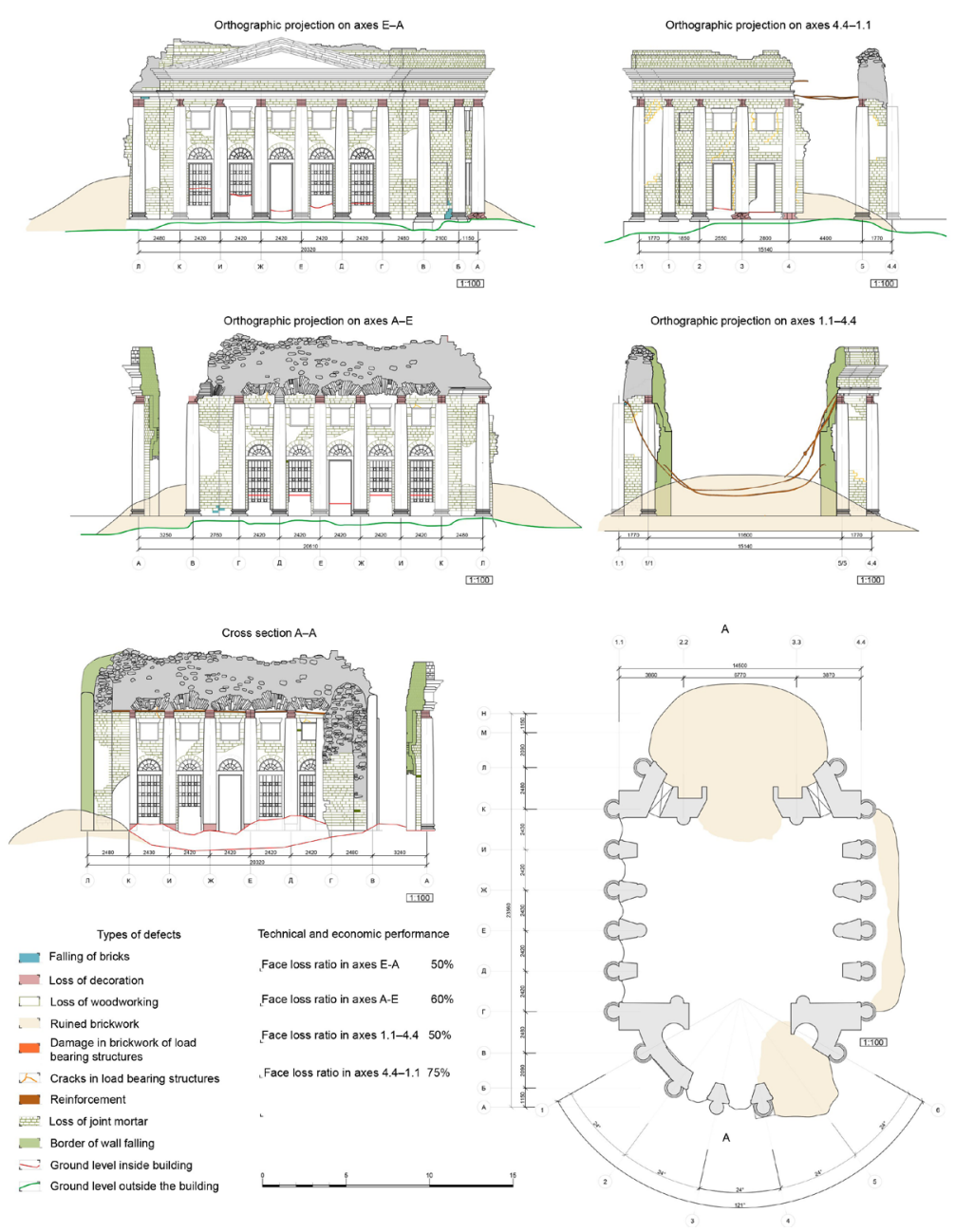

Figure 7. Map of defects 
Proportions of ionic order

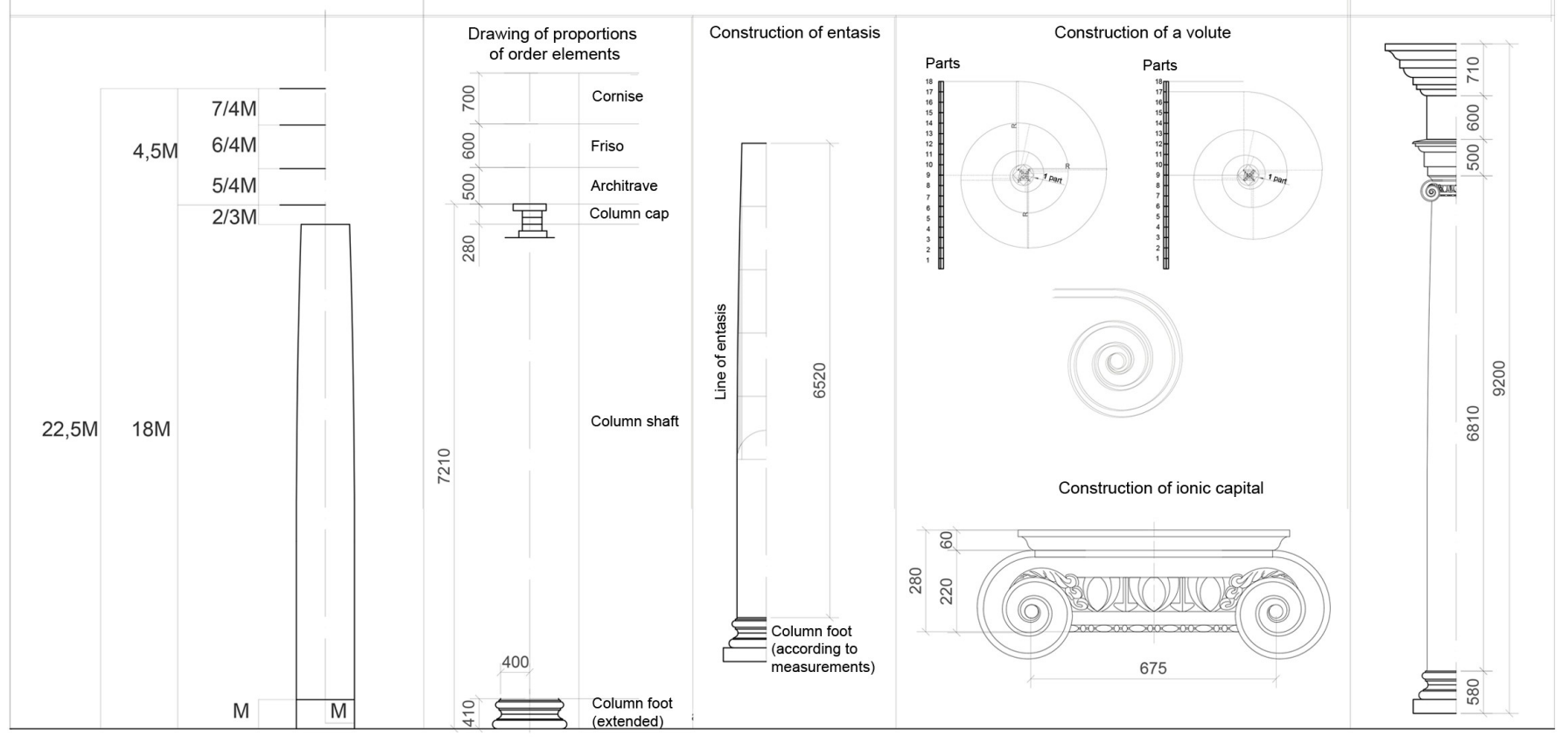

Figure 8. Drawing of proportions of ionic order

that significant collapse of masonry had taken place (Figure 7).

By the present day, there are preserved parts of the walls within lonic order of the face front. In order to make the most accurate order, a scheme of order systems was applied to this project design (Figure 8). A question of proportions of the dome drum and the dome, as well as church completion work remained unclear, but survived iconographic materials make it possible to identify proportions according to perspective pictures; stated method was described in book "The theory of the perspective" by R. Schmidt in detail ( Schmidt, 1983), and was applied in the stated project design.

Architectural solutions of details of Holy Trinity Church can be judged by ruined remains of the church and descriptions of its analogues, as well as surviving Soviet photography and the painting of Church of Exaltation of Holy Cross in village Vyshetarasovka (a direct analogue) written in the 1920 s by artist S. S. Orlov. It should be noted that in the 1880s the St. Petersburg Academy of Arts started a campaign aimed at "delivery of information about ancient Orthodox churches, buildings and art objects to the Academy", collected "with the help of diocesan authorities and local statistical committees". In the 1890s, public registers (sheets with printed standard questions) were transferred to the Imperial Archaeological Commission. Nowadays they are stored in archives of the St. Petersburg Institute of Material Culture History. Besides, fourteen pages describing Pokrovskaya Church (direct analogue) in village Prilepy of the Dmitrievsky County of the Kursk province were preserved. Public register specifies the following information: "Present Church in the name of Holy Virgin is cold, the side-chapel in the name of the Nativity is warm ... It was founded in the year of eighteen hundred twenty-one. It is stony. Church was built at the own expense of the general's wife Olga Konstantinovna Briskorn. It was founded on the level ground near the river Nemyody within the boundaries of the land ownership of Baron von Meiendorf in village of Prilepy of the Dmitrievsky County of the Diocese of Kursk. It is round, built in two floors; the first floor houses a vault... Ground floor of the church was built of rough stone; the first floor was built of bricks. Walls are made of ordinary brick, the middle of the walls are filled with rough stones and mortar... Exterior walls are smooth, unadorned, and decorated with round columns attached to the walls and topped with the cornice in the northern and southern sides of the church... Roof of the church is tent-shaped with four iron slopes... Roof has wooden cornice covered with iron sheets. Lantern is blind, hanged on the smooth neck directly above the arches... Dome of the church is semi-circular, covered with iron... Cross on the church is iron, gilded, four-pointed. Windows in the church are arranged in two tiers: the lower are narrow oblong and the top are small round right under the arch ... Windows have iron lattice. There are three iron doors in the church; they are located on the northern, the southern and the western sides... Interior of the church... Vaults of the church are arranged in semi-circular and founded on round pillars and columns. There are sixteen columns in total in the middle of the church; they are all round, smooth, without any cavities and decoration... Near the western wall... there is a stair way to the lofts and the bell tower ... Iconostasis is made of bass-wood, without any decorations or cuttings... there are two tiers ... There is a belfry in the church placed on roof... there are six bells there... There is no bell tower available. Walls of the church are blue painted since its foundation and currently remain the same... Answers were given by priest Peter Bulgakov from Orlovsky Seminary... Time of register completion: the 1st day of February, 1887" (Bulgakov, 1887). 
According to archive documents "Statement of Inventory... prepared by priest Johannes Shkorbatov" on the construction of the church in village Prilepy, the church looked like as follows as of March 25th, 1823: "Church is stony, single-storey, with two altars. It is dedicated in the name of the Holy Virgin; inside it is round, with col- umns inside and outside, capitals of the ionic order, columns with front faced cornices and medallions of white stone mined from the Myachkovskian area, with lofts for singers, with iron bars on the windows and three iron doors. Length of the church is 57 arshins and width is 36 arshins; basement is masonry; roof is covered with

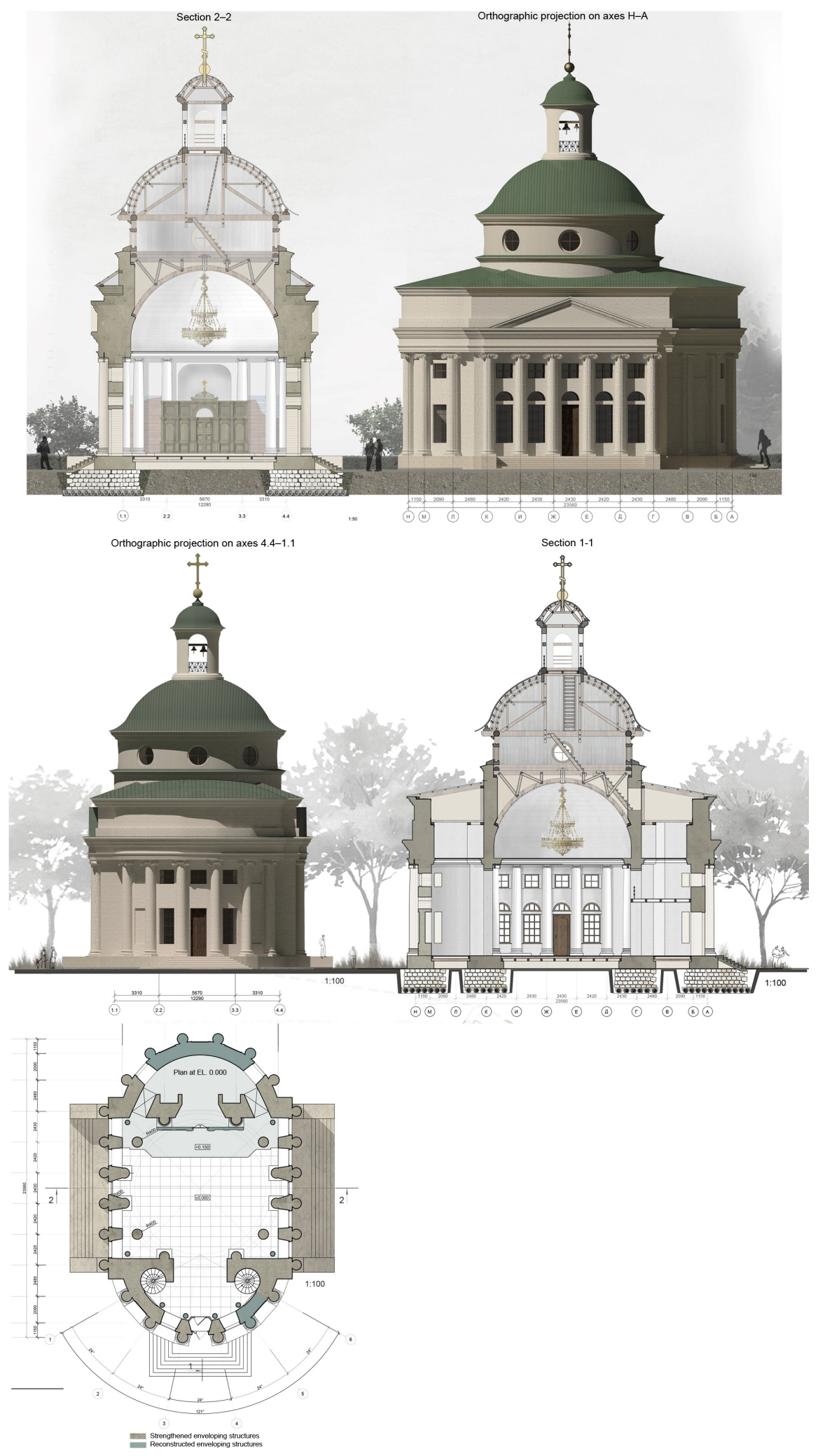

Figure 9. Graphical restoration of Holy Trinity Church in estate Pyataya Gora. student's work. Archives of the SPSUACE 


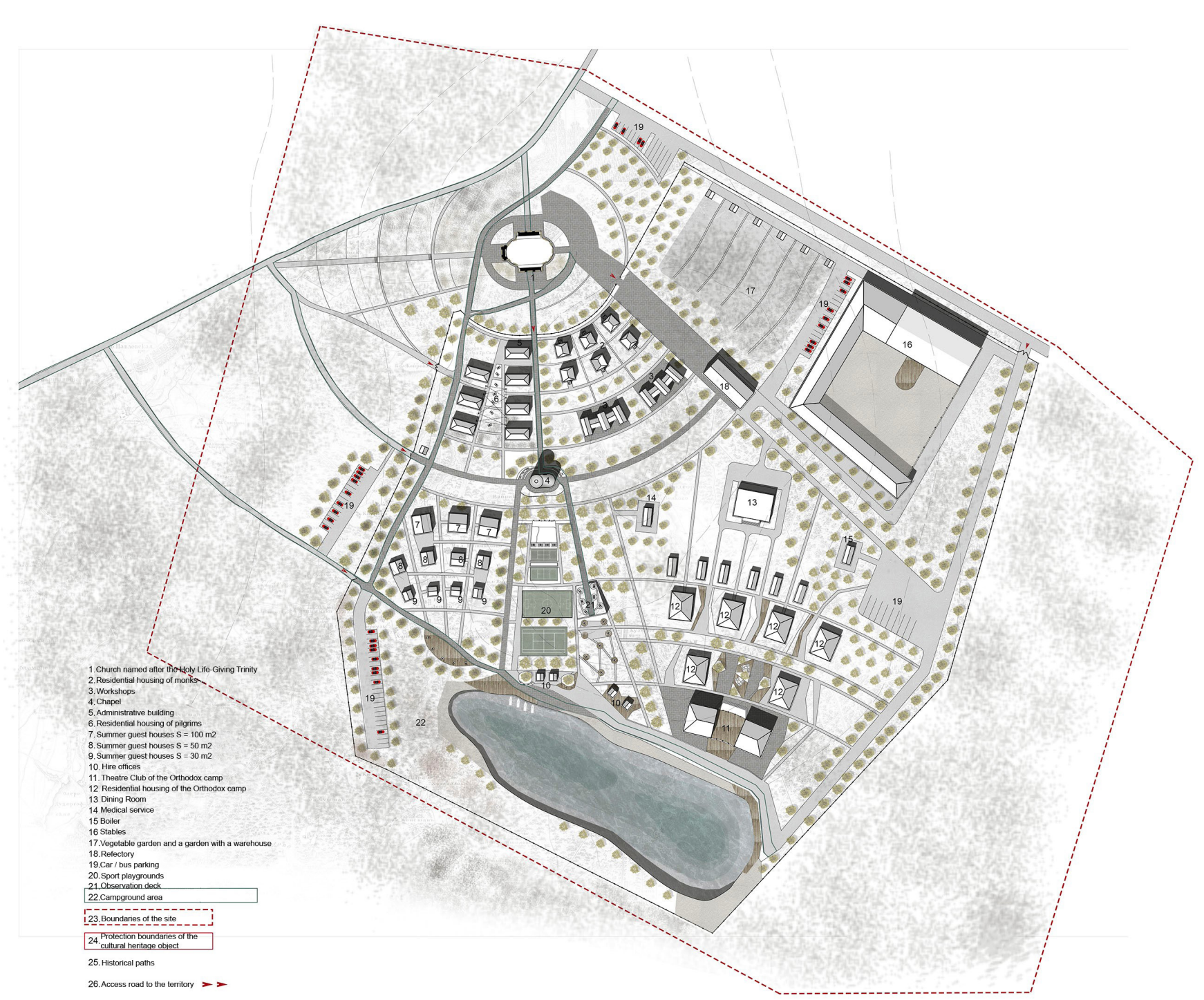

Figure 10. Graphical restoration of Holy Trinity Church in estate Pyataya Gora. Student's work. Archives of the SPSUACE

sheet metal, painted with green paint, with an apple and the cross gilded with fire on the dome; floor in the church and in the altar is cast iron; floor in the warm side-chapel named for the Nativity is wooden, exterior bracings are made of stone; fence is stone with wooden lattice" (Insarsky, 1898).

Archiving of Holy Trinity Church in homestead Pyataya Gora comprises an "Inventory of church property" dated May 1829. An image of soaring Sabaoth cut in wood holding a "chandelier with 18 candleholders, with gilded cherubim and gilded bronze ball inside with a gilded angel and a cross" is pictured on the dome. Iconostasis has "22 images on the right bottom side of the lower tier", among which is the image of the Holy Life-Giving Trinity, a shroud, gilded royal gates with two images of the four evangelists, a baptistery, brocaded anabatas and books, six bells ( 52 pounds one) of 104 pounds in total" (Inventory..., 1829). Also, a surveying of estate Pyataya Gora and a measurement diagram made by the Restoration Factory of the Association "Rosrestavratsiya" in 1977 are present in the archive.

Thus, taking into account the above stated documents, iconographic materials and available archival resources, descriptions and drawings it is possible to restore the church in its historical proportions, dimensions and architectural decoration. Graphic reconstruction of the church was performed by the students of the SPSUACE (Figure 9). Conceptual design comprises the whole dimensions of the church with a dome and a lantern tower, including all decorations of classical architectural forms on the front face. The church interior is supposed to be restored according to verbal descriptions of the interior taken from archival sources, as well as following the analogues of the church constructed in the late XVIII century to the early XIX century.

It should be noted during the reconstruction of Holy Trinity Church that long-lasting safety of the monument and economical justification are possible only under active use and filling with life of the restored object. This is possible only by creating an Orthodox monastery or a church with their own household facilities on the territory of Pyataya Gora estate that will serve as a certain start point for new development of the abandoned territory, while arrangement of a hotel for pilgrims or a camp for orthodox citizens will ensure its inclusion in tourist routes, that, in its turn, will be the source of investments for the 
further development of reconstructed facilities and further new construction. This type of restoration meets all the above stated requirements of functional filling of the area according to the program of regional development. Implementation of the project of an Orthodox children's camp will, among other things, comply with the youth recreation needs.

\section{Conclusion}

The studied materials allow us to make the following conclusions, according to the stated tasks.

The church in the name of Holy Trinity and the surrounding areas of Pyataya Gora estate is of great significance both for the rural settlement Kalitino and for the historically formed landscape. Besides, Pyataya Gora homestead is quite popular destination among tourists. Analysis of the main characteristics of the territory and the regional development plan of the Leningrad region revealed that the most suitable type for the monument restoration is the reconstruction of the historic proportions and structures of the monument. In addition, we propose to renovate the architectural environment of the church and to develop the complex for creation of a monastery metochion in order to promote the place and active use of the territory of the estate. Moreover, the church itself dominates the area, and taking into account the active construction of cottage villages around it, the territory could serve as a significant nucleus of one of the areas of future functional division of the rural settlement Kalitino.

\section{References}

Arabogly, M. (2006). Three estates, three destinies [Tri usad'by, tri sud'by]. Saint Petersburg: Iskusstvo (in Russian).

Briskorn, O. (1829a). [Petition] Saint Petersburg Central State Historic Archive, file 19, inv. 17, doc. 1058, sheet 2 rev. Saint Petersburg.

Briskorn, O. (1829b). [Petition] Saint Petersburg Central State Historic Archive, file 19, inv. 17, doc. 1058 , sheet 82 rev. Saint Petersburg.

Bulgakov, P. (1887). [Public register] Archives of the Institute of material culture history, Public register No. 153, file 21, doc. 675. Saint Petersburg.

Fidelli, V. (1890). [Report] Russian State Historic Archive, file 796, inv. 160, doc. 1073, sheets 5-5 rev. Saint Petersburg.

Insarsky, V.I. (1898). Notes by Vasiliy Antonovich Insarsky [Zapiski Vasilija Antonovicha Insarskogo]. Vol. 6, parts 1-2. Saint Petersburg: Obshestvennaya polza (in Russian).

Inventory of church property (1829). Saint Petersburg Central State Historic Archive, file 19, inv. 17, doc.1058, sheets 153-156. Saint Petersburg.

Restoration of museum valuables. Bulletin [Restavracija muzejnyh cennostej. Vestnik] (1998). No. 1, pp. 55-58.

Schmidt, R. (1983). Theory on perspective [Uchenie o perspective]. Moscow: Stroyizdat (in Russian).

Short economic notes of the Rozhdestvensky County (1789). Russian State Historic Archive, file 1350, inv. 312, doc. 127, sheet 19. Saint Petersburg. 